\title{
Bedside test for diagno- sis of oedema fluid after extradural anaesthesia
}

\author{
Alexander Zeidel MD, * \\ Arie Gingold $M D, \dagger$ \\ Elena Satunovsky MD, * \\ Ethan E. Harow MD, * \\ Ben-Zion Beilin MD*
}

Purpose : To consider and differentiate oedema fluid from other fluids in the performance of epidural block.

Clinical features: A patient underwent placement of an epidural catheter for vaginal delivery of twins. Following a loss of resistance technique using air a small amount of fluid was aspirated through the needle and subsequently through the epidural catheter. The epidural block and delivery followed uneventfully. After delivery oedema fluid oozed from the puncture site for a number of days. Laboratory investigation revealed that this fluid was of oedematous origin. Bedside determination of alkaline $\mathrm{pH}$ by Combur 10 Test $M$ urine stick appeared to be a simple and useful test for distinguishing the oedema fluid from fluids of other possible sources.

Conclusion: When performing an epidural blockade the return of fluid may be due to oedematous fluid. Differentiation of the $\mathrm{pH}$ by a simple bedside test can aid in the differential diagnosis and prevent unnecessary additional attempts at needle repositioning.

Objectif : Examiner le liquide d'un œedème et le différencier des autres liquides lors d'une anesthésie péridurale. Éléments cliniques : Une patiente a subi la mise en place d'un cathéter péridural pour l'accouchement de jumeaux par voie vaginale. Après avoir utilisé la technique de perte de résistance à l'air afin d'identifier l'espace péridural, une petite quantité de liquide est passée par aspiration dans l'aiguille et, plus tard, dans le cathéter péridural. L'anesthésie et l'accouchement se sont déroulés sans incidents. Après l'accouchement, du liquide d'œdème a suinté, au site de ponction, pendant quelques jours. L'examen de laboratoire a révélé que ce fluide était d'origine œdémateuse. La détermination du $\mathrm{pH}$ alcalin, réalisée au chevet de la patiente avec un bâtonnet pour test d'urine $M$ de Combur 10 , est apparue comme une mesure simple et utile pour distinguer le liquide d'œdème des autres sources possibles.

Conclusion : Lors de l'exécution d'une anesthésie péridurale, le retour de liquide peut être d'origine œdémateuse. La qualification du $\mathrm{pH}$, par un simple test réalisé au chevet de la patiente, peut aider à poser un diagnostic différentiel et à supprimer d'inutiles ponctions additionnelles.

From the Department of Anesthesiology, ${ }^{*}$ Obstetrics and Gynaecology, $\dagger$ Rabin Medical Center, Campus Golda (Hasharon), Keren Kayemet Le Israel str, Petach-Tikva, 49372, Israel. Fax:972-3-9372332

Address correspondence to: Ben-Zion Beilin MD.

Accepted for publication April 11, 1998. 
$\mathrm{U}$ NINTENTIONAL dural puncture when performing epidural blockade in obstetric practice is an undesirable and potentially serious complication if undetected. ${ }^{1}$ This distressing complication may lead to a further attempt at needle insertion, performance of prophylactic blood patch or transition to less effective methods of analgesia. $^{2}$ In addition to CSF other fluids aspirated through the epidural needle include local anaesthetic solution or normal saline used for the loss of resistance technique. Another possible aspirate is oedema fluid.

We present a case in which bedside $\mathrm{pH}$ determination by Comburl 0 Test $M$ urine stick was used for the differential diagnosis of continuous leakage of oedema fluid after epidural block.

\section{Case Report}

A $33 \mathrm{yr}$ old previously healthy primigravida with a term gestation and well established labour presented for epidural analgesia. Her in vitro fertilization induced twins pregnancy was unremarkable except for the development of moderate peripheral oedema during the last weeks of pregnancy. Her blood pressure and urinary tests were normal.

Following $i v$ hydration with $1000 \mathrm{ml}$ normal saline the patient was placed on her side. After sterile preparation and draping, local anaesthesia was infiltrated with $1.5 \mathrm{ml}$ lidocaine $1 \%$. An 18 gauge Tuohy needle was inserted at the $L_{3.4}$ interspace. Identification of the epidural space was achieved by a loss of resistance technique using air. A drop of clear fluid appeared at the needle port initially, but further aspiration was negative. An epidural catheter was introduced and attempted aspiration provided a very small amount of fluid that filled part of the catheter. A test dose with 3 $\mathrm{ml}$ lidocaine $1 \%$ was negative after five minutes. Bupivacaine $0.25 \%$ solution was injected by incremental doses of $2-3 \mathrm{ml}$ to a total of $10 \mathrm{ml}$. Analgesia was achieved within $10 \mathrm{~min}$ without haemodynamic changes or motor blockade. Repeated doses proceeded uneventfully. Six hours later, an uncomplicated vaginal twin delivery occurred and the epidural catheter was removed.
After catheter removal continuous leakage of a transparent fluid from the puncture site was observed during the next three days. The rate of fluid leakage started at 6-8 $\mathrm{ml} \cdot \mathrm{hr}^{-1}$ and slowly decreased thereafter. The patient had no complaints. Physical and neurological examination was normal except for peripheral oedema up to the knees. There was no pain or visible oedema at the site of the epidural injection. Computerized tomography scan of the spine did not reveal any pathological collection of fluid. The only abnormal blood test was hypoalbuminaenia of $22 \mathrm{~g}$. $\mathrm{L}^{-1}$. During the period of observation, several samples of oozing fluid were collected and sent for laboratory examination (Table). Both laboratory determination and bedside testing using Comburl0 Test $M$ for Miditron by Boehringer Mannheim urine sticks showed alkaline $\mathrm{pH}$ of 7.74 and 8 respectively which differentiated this transudate from other possible aspirates. The patient stayed in the hospital for five days and was treated by $20 \mathrm{mg}$ furosemide iv daily. By day 4 the leakage had stopped with gradual disappearance of the peripheral oedema. No further medical problems were reported.

\section{Discussion}

Comparison among different aspirates shows that the investigated fluid most closely resembles oedema transudate by its protein content and alkaline $\mathrm{pH}$ (Table).

We have not investigated whether the source of the leakage was the epidural space itself or the soft tissues surrounding the puncture site. The low pressure and distensibility of the epidural space make it a probable site for the transudate accumulation in susceptible patients. In this case hypoalbuminaemia was an aggravating factor for oedema formation. It must be remembered, however, that normal pregnancy has up to $80 \%$ clinically apparent oedema with nearly half being generalized. ${ }^{3}$ At term, the increase in extracellular fluid reaches up to seven litres. Leg oedema comprises only $0.5 \mathrm{~L}$. of the total. ${ }^{3}$ Thus, the majority of the oedema presents in other areas including the lower back even when undetected by physical examination. Under these circumstances an epidural needle or

TABLE 12,13

\begin{tabular}{llllllll}
\hline Fluid & $\begin{array}{l}\text { normal } \\
\text { plasma }\end{array}$ & $\begin{array}{l}\text { patient } \\
\text { plasma }\end{array}$ & CSF & $\begin{array}{l}\text { normal } \\
\text { saline }\end{array}$ & $\begin{array}{l}\text { lidocaine } \\
1 \%, 2 \%\end{array}$ & $\begin{array}{l}\text { oedema fluid } \\
\text { (Pleural transudate) }\end{array}$ & $\begin{array}{l}\text { investigated } \\
\text { fluid }\end{array}$ \\
\hline cells $\cdot \mathrm{mm}^{-3}$ & & & $0-5$ & & & $1000-5000$ & \\
$\mathrm{pH}$ & $7.35-7.44$ & 7.41 & $7.34-7.43$ & 5.0 & 6.1 & 7.64 & 7.74 \\
total protein $\mathrm{g} \cdot \mathrm{L}^{-1}$ & $50-80$ & 41 & $2.5-4.5$ & 0 & 0 & $18-28$ & 17.4 \\
glucose $\mathrm{mM} \cdot \mathrm{L}^{-1}$ & $3.58-6.05$ & 4.31 & 4.4 & 0 & 0 & $3.85-6.6$ & 6.64 \\
sodium meq. $\mathrm{L}^{-1}$ & $135-145$ & 137 & $135-145$ & 145 & & $135-145$ & 139 \\
\hline
\end{tabular}


catheter can serve as a drain for interstitial fluid. Leakage of oedematous fluid after epidural anaesthesia has been reported several times. ${ }^{4-6}$ We initially observed only a small amount of fluid, but subsequent follow-up demonstrated that transudate leakage may be considerable.

It is important to differentiate harmless oedema leakage from a "wet tap" of inadvertent dural puncture and continuous spinal-cutaneous fistula when appropriate treatment, e.g. blood patch, fibrin glue patch, skin stich, should be given..$^{7,10}$ This problem was addressed by using biochemical assay for electrolytes, protein content and specific acetylcholinesterase. ${ }^{4-6,11}$ All these tests delay a diagnosis for time of laboratory examination and impose additional cost. Also, a sample may be too small for laboratory measurement when obtained during performance of epidural block. Bedside determination of $\mathrm{pH}$ overcomes these pitfalls. Although our decision to continue was based on negative further aspiration and a negative test dose, the subsequent laboratory testing demonstrated that $\mathrm{pH}$ determined by Combur 10 Test $M$ urine stick was an easily available, rapid and simple bedside test to differentiate oedematous fluid from leakage of other sources.

In conclusion, in patients with signs of peripheral oedema and predisposing factors for transudate formation, the possibility of oedema fluid leakage associated with epidural block should be considered. A low pressure leakage of fluid with high $\mathrm{pH}$ indicates oedema.

\section{References}

1 Scott DB, Hibbard BM. Serious non-fatal complications associated with extradural block in obstetric practice.

Br J Anaesth 1990; 64: 537-41.

2 Colonna-Romano P, Shapiro BE. Unintentional dural puncture and prophylactic epidural blood patch in obstetrics. Anesth Analg 1989; 69: 522-33.

3 Davison JM. Edema in pregnancy. Kidney Int 1997; 51(Suppl 59): S90-6.

4 Ennis M, Brock-Utne JG. Delayed cutaneous fluid leak from the puncture hole after removal of an epidural catheter. Anaesthesia 1993; 48: 317-8.

5 Downey L, Slater EM, Zeitlin GL. Differentiating interstitial fluid from cerebral spinal fluid (Letter).

Anesthesiology 1985; 63: 120.

6 Kirby IJ, Ryan TDR. Generalised oedema and epidural anaesthesia (Letter). Anaesthesia 1985; 40: 709-10.

7 Hullander M, Leivers D. Spinal cutaneous fistula following continuous spinal anesthesia. Anesthesiology 1992; 76: 139-40.

8 Gerritse BM, van Dongen RTM, Crul BJP. Epidural fibrin glue injection stops persistent cerebrospinal fluid leak during long-term intrathecal catheterization. Anesth Analg 1997; 84: 1140-1.
$9 \mathrm{Katz}$ J. Treatment of subarachnoid-cutaneous fistula with an epidural blood patch. Anesthesiology 1984; 60: 603-4.

10 Jawalekar SR, Marx GF. Cutaneous cerebrospinal fluid leakage following attempted extradural block. Anesthesiology 1981; 54: 348-9.

11 Vanner RG. Acetylcholinesterase - a specific marker for cerebrospinal fluid. Anaesthesia 1988; 43: 299-300.

12 Friedman $H H$. Problem-Oriented Medical Diagnosis. Boston/Toronto: Little, Brown and Company, 1988: 401.

13 Staub NC, Taylor AE. Edema. New York: Raven Press, 1984: 699. 